\title{
Kirk and Wittkopf share their visions for ACRL
}

By Thomas G. Kirk

College Librarian

and Professor of Library Science

Berea College

\author{
and Barbara Witkopf
}

Reference Librarian

Louisiana State University

\section{ACRL's 1992 presidential candidates'statements.}

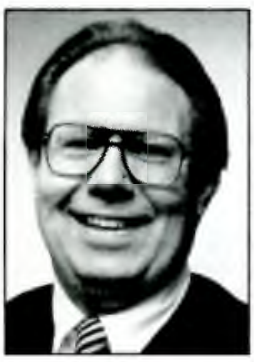

Thomas G. Kirk

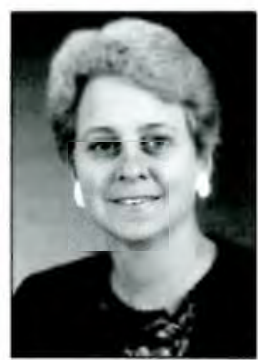

Barbara Wittkopf d. Note: C $\checkmark R L$ News offered ACRL candidates for vice-president/president-elect, Thomas Kirk and Barbara Wittkopf, this opportunity to share their views with the ACRL membership. Although many of the issues and concerns facing ACRL are discussed informally at meetings, this does not provide a national forum available to all members. We hope that providing this forum will assist you in making an informed choice when you receive your ballot from ALA next month.

\section{Thomas G. Kirk}

Twenty-three years of experience in ACRL, SOLINET, and other professional associations has demonstrated to me the value of work in library organizations. The work has been rewarding to me personally and the value to the profession of cooperative work done through such organizations is very evident to me. Election to the position of ACRL vice-president/ president-elect will give me the opportunity to act on three challenges which I believe ACRL should address. They include more sustained and intensive networking with higher education and professional associations, more intentional coordination of our work with ALA and the other divisions, and strengthening our planning and communication efforts within ACRL. I welcome the opportunity to work with the many volunteers who serve on committees, boards, and task forces of ACRL and its sections. It is through their efforts that ACRL achieves the goals in its Strategic Plan. This introduction provides a brief overview of the directions I will take as president of ACRL. In the space below I spell out the rationale for these directions and elaborate on the three elements of my platform.

\section{Background}

When most librarians see the term "networking" what probably comes first to their minds are OCLC, NREN, SOLINET, or whatever is the acronym of their particular interlibrary organization, an organization which has resource sharing, usually through application of technology, as its central goal. But networking is also a social term - individuals connecting to share their human resources in order to solve a particular problem or search for a solution to 
a special challenge. I like to think of ACRL as a network for academic and research librarians through which they can connect with each other and with the larger library and academic community.

In my 23 years of membership in ACRL and ALA I have seen how networking has helped us pass important milestones in the development of the association. One milestone that immediately comes to mind is the creation first of the Task Force on Bibliographic Instruction and later of the Bibliographic Instruction Section. I and other active bibliographic instruction librarians, through extensive communication and consultation with the members, encouraged ACRL to provide an organizational base for this emerging library service. Through this section academic librarians have continued to address important issues as bibliographic instruction has developed into a basic service of academic and research libraries. Today, BIS is one of ACRL's most active sections and, along with other sections, has extended ACRL's program in support of academic libraries and librarians.

Networking was also responsible for gaining better relationships among the divisions of ALA. Through communication among the leaders of the various divisions conflict among divisions has been reduced and thus permitted the divisions to have a stronger voice within ALA.

As President of ACRL I would like to address three areas in which networking can strengthen ACRL and our ability to achieve ACRL's mission.

\section{Communication within ACRL}

First, I see a need to improve our own connections within ACRL. As a large division with the diversity of interests reflective of academic and research librarianship generally it is easy for us to become fragmented and lose sight of our overall goals. Nowhere is this more evident than in conflicts that emerge over budget and areas of responsibility. I am committed to finding ways in which parts of the organization can be better informed about the work of the entire association.

The connections between the ACRL Board of Directors and the committees and sections of ACRL particularly need strengthening. While I was a member of the Board of Directors in 1979-81 and again from 1986-1990, the Board experimented with various ways of improving communication with ACRL units. Building on that experience I want to develop more effective mechanisms for demystifying the work of the Board and sharpen the Board's understanding of the work of the sections and committees of ACRL.

Some time ago I wrote to various members of the ACRL leadership asking for suggestions about how to strengthen the ACRL network. Here are a few of the suggestions I received: communicate ACRL activities through Chapter Topics, the newsletter of the Chapters Council; solicit input from member-

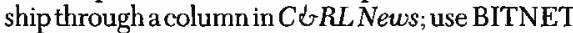
toimprove communication among committee members; have an open forum for ACRL Board and ACRL membership at Annual Conference. These suggestions among others from the membership will be explored as part of my effort to stimulate the ACRL network.

\section{Connecting with other parts of the whole}

Second, we need to foster our connections with ALA in general and with its divisions. As a division of ALA our ability to address major issues effecting academic and research librarians and libraries is intertwined with the work of ALA generally and its other divisions. As I sat on ALA Council and participated in deliberations about ALA's programs in the areas of legislation, literacy, intellectual freedom and censorship, public attitudes towards libraries, and access to government information, I became more aware of the value of these programs to academic and research libraries. I am also aware that other divisions address such professional concerns as reference services, collection development, library automation, and library administration which are important to academic and research libraries. Our challenge as members of ACRL is to connect our work to that of ALA and its other divisions. I will be looking for ways in which ACRL and ALA and its other divisions can be better informed about one another's programs and mutually supportive.

\section{Connecting with the rest of higher education}

Third, we should enhance our connections with higher education and professional associations. I want to affirm and continue the program area of this fundamental goal. The ACRL Professional Association Liaison Committee is exploring ways to enhance our ability to connect with other associations. While there has been no lack of effort in the past (see JoAn S. Segal and Sandra Whiteley in C\&RL News, July/August 1990), effective networking with other associations will not occur unless we can find the mechanisms to integrate the networking into the organizational fabric of ACRL. I have firsthand experience as one of two ACRL representatives to the Coalition for Networked Information, and with this experience I have learned something of the challenges and benefits of ACRL's networking with other organizations. Because the challenge is so great I don't expect a simple solution, but we should look to take further steps that will develop continuing relationships with higher education and professional associations. 


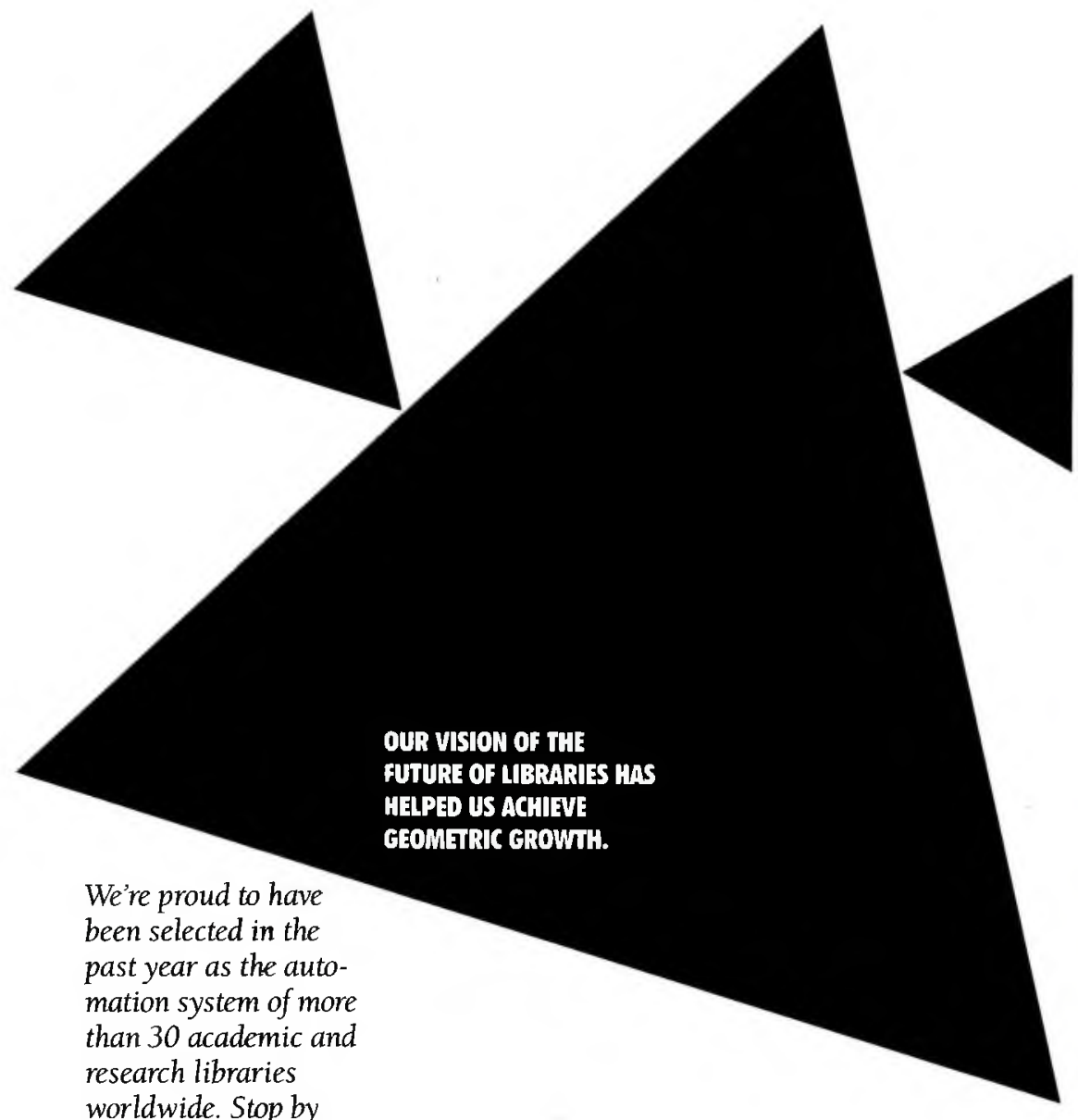
booth 227 at the ACRL conference to find out why.

\section{DATARESEARCH}

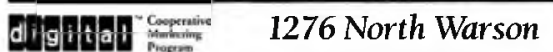

P.O. Box 8495

St. Louis, MO 63132

Internet:

Sales@dranet.dra.com 


\section{Final thoughts}

In their article "Communication in a 'Network' organization" (Organizational Dynamics, Autumn 1991), John B. Bush and Alan L. Frohman note that the traditional hierarchal modes of communication are not sufficient if an organization is to be innovative and promote change. They call for a networking structure that allows, I would say, encourages, lateral communication and promotes creativity. I believe we can improve the Association and our members by exploring how to create a "networked organization."

These areas of concern-how to improve networking among ACRL members, between ACRL and other ALA divisions, and with higher education and professional associations outside ALA — can be addressed individually and collectively. Collectively, ACRL needs to give attention to the dynamics of its organizational structure and search for mechanisms which will enhance, even reward, efforts to connect with other groups. Individually, we need to explore the dynamics of networking as a personal and professional style of work. Through a focus on networking and the mechanisms for building the connections among ACRL, its constituent parts, and the larger world of librarianship, higher education, and research, ACRL will be better able to achieve the goals which support ACRL's mission.

The priorities I have outlined above are intended to advance ACRL's focus on its stated mission and goals. I support the ACRL Strategic Plan and believe it should inform and direct the work of the association. The Strategic Plan is an important tool of organizational development and it must continually be renewed and informed by our experience. I want to see the planning process strengthened so that we are more unified in our vision of what ACRL can be.

I also know that certain unplanned ideas and events arise during a president's term. I believe that the president of ACRL must actively meet those challenges. My style will be to consult widely with the Executive Committee, Board of Directors, and/ or the appropriate ACRL committees, councils, or sections. ACRL's strength lies in the wealth of knowledge, ingenuity, and commitment of its volunteer members who serve on these association bodies. In making decisions for the association, I want to promote a more unified vision of the goals of the Association and improve the effectiveness of our programs in meeting those goals.

\section{Barbara Wittkopf}

The mission of ACRL is twofold:

1) It exists to enhance the ability of academic and research libraries to effectively serve the library and information needs of their users--current and po- tential, and 2) It fosters the profession of academic and research librarianship.

ACRL is the largest division of Al A with 11,000 members, 255 committees and discussion groups, three type-of-library sections, 13 type-of-activity sections, 22 liaison committees, and 41 chapters.

These groups work with the ACRL staff, Executive Board, and Board of Directors to accomplish this task. I have chaired the Bibliographic Instruction Section and Activities Section Council and am currentlyon the Board of Directors. I would like to serve as president of ACRL to help it achieve its mission.

Increasing restraints on human, financial, and political resources demand that more information be shared, that duplication of efforts be kept to a minimum, that activities be prioritized, and that "models"-large and small--be created to disseminate the strategies and programs that are developed.

This approach is cost and time efficient and provides a service to all ACRL members, in all types of academic and research libraries whether or not members are able to attend national meetings.

All ACRL activities, programs, and publications should be perceived by members as relevant and significant to their job responsibilities or to their role as academic or research librarians.

\section{Using WHCLIS to advantage}

In the aftermath of the White House Conference, national attention is focused on library and information services. ACRL can use this climate to advantage.

One of ACRL's four goals is "to promote and speak for the interests of academic and research librarianship." It is the division within AI_A charged with the responsibility for addressing issues related to higher education.

\section{Enhancing communication}

Institutional accreditation. How effectively are academic and research libraries meeting the needs of their users? All academic and research librarians need to address this question at their institutions.

Colleges and universities are assessing their effectiveness in qualitative as well as quantitative terms. Librarians should be eager partners and participants in this process.

In addition to consulting the performance evaluation manual commissioned by ACRL, librarians need to further identify ways of measuring success.

Goal 2 of the ACRL Strategic Plan is to "enhance the capability of academic and research librarians to serve the needs of users,"

Two years ago the three ACRL type-of-library sections held a combined conference program on performance evaluation. The manual was discussed 
and a discussion group was formed. At the ACRL Standards and Accreditation Committee program in Atlanta representatives from accrediting agencies emphasized the need for more qualitative data.

Information from these and other ALA activities should be brought together and shared through ACRL committee work, publications, programs, and workshops.

This evaluative process will result in improved service to users and will assist institutions-large and small-who are participating in one of the six regional accreditation review programs.

Library schools. Recent editorials suggest that librarians "stop bashing library education." Academic librarians are most physically linked to library schools and should be among their most ardent supporters.

ACRL sends representatives to the ALA Standing Committee on Library Education. ACRL members need to be more aware of the policies and recommendations made regarding the educational preparation of all library personnel.

Library schools, too, are debating criteria for accreditation. This year's ACRL presidential theme is recruitment. Academic librarians who hire the graduates these programs produce should be concerned with the outcome of their decisions: to have accreditation criteria or not; to be accredited or not.

ACRLand its informed personal members should communicate their opinions to library school deans and their faculties.

WHCLIS recommendations. Librarians may be overwhelmed by the 97 recommendations and six petitions adopted by the 697 voting delegates to the 1991 White House Conference on Library and Information Services.

ACRL should identify and support WHCLIS recommendations relating to higher education. These include support for: NREN, the electronic superhighway; the Higher Education Act; the Library Services and Construction Act, especially regarding Library Literacy; College Library Technology Demonstration Grants; information preservation; multicultural/multilingual programs; copyright related to new technologies; and freedom of access.

ACRL must continue working with the ALA Washington Office to assure that sufficient funds are provided so that libraries can acquire, preserve, and disseminate information resources needed for education and research.

College \& Research Libraries News. ACRL leaders and committees can continue to communicate with members through the division's official news publication, C\&RL News.

Key issues can be highlighted and explained. The status of legislation can be listed in the "Washington Hotline." Chapter representatives can communicate to their constituencies so they will be knowl- edgeable in effectively communicating with their legislators.

ACRL should have a goal of establishing a chapter in all 50 states.

Legislation and programs. The need for legislative support can be tied to ACRL sponsored or COsponsored programs on effective statewide electronic networking, preservation strategies, multilingual database construction, and the like. ACRL should determine how much association activity and time should be devoted to legislative matters.

Professional liaisons. Many ACRL members are unaware that ACRL has representatives to the American Association for Higher Education, American Association for the Advancement of Science, American Association of University Professors, American Chemical Society, American Council on Education, Association of American Colleges, Modern Language Association, and National Forum on Information Literacy, to name a few.

Personal members are also active in other professional associations as well as ALISE, ASIS, SAA, and EDUCOM.

$A C R L$ is the only group within ALA with membership in the Coalition for Networked Information. Benefits and responsibilities from these affiliations should be made more widely known to ACRL members.

America 2000. Last year's ACRL theme was literacy. The America 2000 Excellence in Education Act, while primarily related to elementary and secondary school environments, also provides an opportunity for higher education institutions - and their libraries - to help America attain the National Education Goals.

ACRL can draw attention to the role of libraries in reducing illiteracy in the lifelong education process; forward the information on literacy accumulated last year to the Regional Literacy Resources Centers established by this act; collaborate with teaching faculty in training programs for the Governors' Academies in promoting critical thinking skills across the curriculum; and forward members' names to the task forces and advisory groups the WHCLIS delegates recommended to the president.

Sections and chapters. Sections, chapters, and discussion groups attract many members to ACRL.

Sections. ACRL is responsive to group requests to form or change to meet members' current needs. The newest sections have included Extended Campus Library Services, Womens' Studies, and Science and Technology.

The more long-standing Rare Books and Manuscripts Section continues to provide successful annual preconferences and activities. The Bibliographic Instruction Section has created new committees that reflect emerging new technologies and diverse user population groups. ACRL, likewise, has established division committees and task forces to respond to social issues, cultural diversity, etc. 


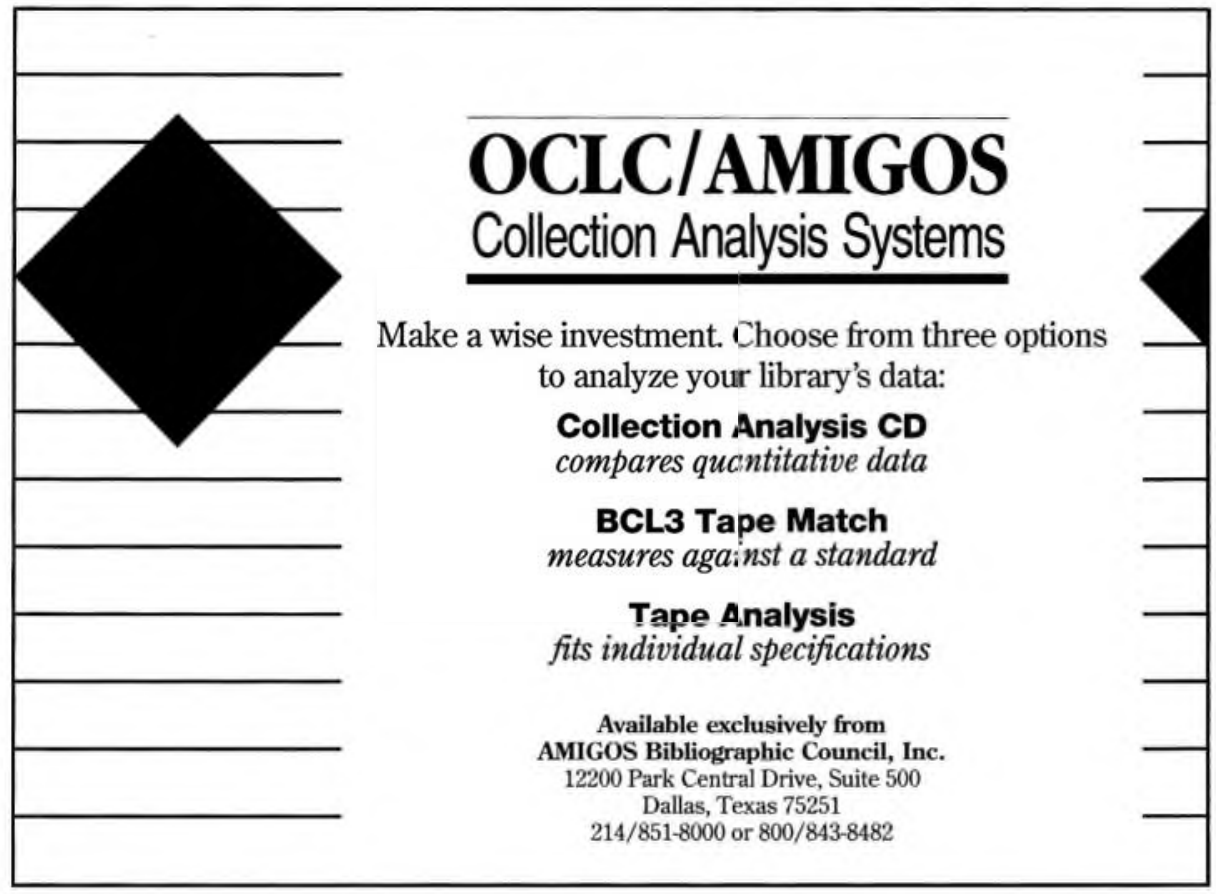

News of section activities is primarily reported in the section newsletters.

Chapters. Chapters are celebrating their 20th anniversary this year. News about their activities is shared primarily at Chapter Council meetings at ALA and in their publication, Chapter Topics. Most of this information reaches only the eyes and ears of chapter officers.

To enhance communication with one another chapters summarized the content of their programs this year in addition to listing themes and speakers.

Further internal communication. Activities Section Council (comprised of officers from each section) and Chapters Council (representing the greatest grassroots contacts within the division) should be encouraged to report to the Board each conference to provide feedback and to share recommendations or concerns.

In addition to noting the more formal standards and publications, CuRL News can be used to communicate the existence, availability, or status of the more informal checklists, bibliographies, and surveys, etc., prepared at all levels within ACRL.

This information will ultimatelyneed to be combined at the ALA level to provide a "corporate memory" across time and across division and round table lines.

"Unity Through Diversity." This slogan was embraced by the divisions a year ago to emphasize the unique contributions of each division within ALA.
All ACRL committees and discussion groups should: identify other ALA groups with common interests or agendas, cosponsoring programs where appropriate; assess the need to meet more than one time, especially at annual conference, where these programs are presented; and incorporate ways to package and market their programs to make the materials more transferrable to local institutions or chapters.

ALA. ACRL is responsive to ALA, its mission, priorities, and agendas. ACRL presidents meet with other division leaders and ACRL has a representative on ALA Council who reports to the Board.

\section{Personnel narrative}

$\Lambda C R L$ is well-organized. It has strong leaders, a competent, responsive staff, and is guided by a Strategic Plan.

In addition to my membership in ACRL, I am a member of Beta Phi Mu, RASD, LAMA, and LIRT. Since 1989 I have been editor of Research Strategies. My articles have appeared in CURL News, $J A L$, and $R Q$.

I have worked in two ARL libraries with positions as head of general reference in asocial sciences/humanities library and director of an agriculture library.

I would like to apply my years of experience in ACRL by serving as its president. 